\title{
HEALTH STATUS AND DIETARY PATTERNS IN POLAND
}

\author{
Anna Dąbrowska ${ }^{1 凶}$, Liudmyła Shulgina², Anita Szuszkiewicz ${ }^{1}$ \\ ${ }^{1}$ SGH Warsaw School of Economics, Poland \\ ${ }^{2}$ National Technical University of Ukraine, Ukraine
}

\begin{abstract}
The main goal of this paper is to evaluate the health status of Poles in the context of their dietary patterns. Results of a desk research study on dietary habits of persons working during the coronavirus pandemic and attitudes of Poles towards meal delivery services provided to the authors by external research institutions were utilized for the purpose of the article. In the framework of practical scientific cooperation, the following reports containing results of research on dietary patterns of people working during the pandemic have been made available for the purpose of this study: "Healthy, speedy or conveniently?" and "Healthy eating". The results were used with retain of copyright and ethical principles. Data analysis led to the conclusion that people have tended to pay more attention to the food intake as well as spend more time on self-preparation of meals during the pandemic. Based on analysis of the study results, a thesis was formulated that during a pandemic, we pay more attention to what we eat, and we also spend more time preparing meals on our own. Assuming that the population of Poland in 2020 was 38,265 thousand people, it could be stated in the light of the study results that almost 650 thousand Poles were on a well-balanced diet adapted to individual consumer needs.
\end{abstract}

Key words: farm, diet, health, eating habits, Poland

JEL codes: I12, I31, P4

\section{INTRODUCTION}

Good health is one of the greatest human blessings. It is not something that can be taken as a lifelong 'given' - it must often be acquired and maintained, as can knowledge relating to good health [Harari 2015]. The importance of good health could be presented in its essence by citing a Polish poet, Kochanowski, who wrote in his well-known epigram "On Health": My good and noble health, Thou matter'st more than wealth. None know'th thy worth until Thou fad'st, and we fall ill. And every man can see, in stark reality, and every man will say: 'Tis health I need today'. No better thing we know, no dearer gem we owe (...)"[Kochanowski n.d.].

As pointed out in the Constitution of the World Health Organization, the definition of health encompasses complete absence of disease or infirmity. It is also understood as "a state of complete physical, mental and social well-being". This approach emphasizes social and personal resources, as well as physical capacities that correlate with health:

- the enjoyment of the highest attainable standard of health is one of the fundamental rights of every 
human being without distinction of race, religion, political belief, economic or social condition,

- the health of all peoples is fundamental to the attainment of peace and security and is dependent upon the fullest co-operation of individuals and States,

- the achievement of any State in the promotion and protection of health is of value to all,

- unequal development in different countries in the promotion of health and control of disease, especially communicable disease, is a common danger,

- healthy development of the child is of basic importance; the ability to live harmoniously in a changing total environment is essential to such development,

- the extension to all peoples of the benefits of medical, psychological and related knowledge is essential to the fullest attainment of health,

- informed opinion and active co-operation on the part of the public are of the utmost importance in the improvement of the health of the people,

- governments have a responsibility for the health of their peoples which can be fulfilled only by the provision of adequate health and social measures [WHO 2006].

The aim of the programme "Health 2020" set by 53 countries in September 2012 is to significantly improve health and overall well-being of societies, provide equal access to medical care, strengthen the public health sector, and guarantee that people-centred health systems are universal, fair, sustainable and of the highest quality. The main theme of the World Health Day in 2021, celebrated on April 7th, was building a fairer, healthier world. It was also stressed that the pandemic of COVID-19 has brutally exposed and deepened inequalities in societies. There is a clear dichotomy between social groups that are in a privileged position to live healthier lives with greater access to healthcare services due to the conditions in which they are born, grow, live, work and age - and those who do not have such privileged social background and consequently no such possibilities. The second group is often doomed to worse living conditions that are interconnected with a broad range of inequalities in people's lives along with medical care, education, unequal opportunities in the labour market or even poverty in its worst scenarios. As a result, this leads to unnecessary anguish among people who suffer from a wide range of diseases, as well as premature deaths that could certainly be avoided under different existential conditions. This is the reason that, at the World Health Day, leaders were called upon by the World Health Organization to monitor health inequalities and provide everyone with a high quality of medical services.

The COVID-19 pandemic has overwhelmed healthcare systems around the world, but its impact has been especially harsh on communities that already suffer from inequal or no access to medical services, as well as economic inequalities. It can be assumed that in the context of those social groups there is no question of the possibility for equal access to healthcare services of good quality - or even no such access - which contributes to the high mortality of COVID-19 infections among unprivileged layers of society. The WHO has taken efforts to counteract this phenomenon; however, the question arises as to whether this is even possible.

The results of a study conducted by Dąbrowska and Janoś-Kresło of the pandemic in four European countries over the period of August-September 2020 confirmed that people tended to focus more on health issues and the closest family during this time - this was according to $58.2 \%$ of respondents in Poland, $62.5 \%$ in Germany, $52.6 \%$ in the Czech Republic and $72.1 \%$ in Italy ${ }^{1}$. A response to the COVID-19 program for the European Union's action in the field of health ('EU4Health Programme') for the period 2021-2027 was established by the EU Regulation 2021/522 of the

\footnotetext{
${ }^{1}$ The study was conducted on the following samples using CAWI method: Poland $N=1001$ respondents; Czech Republic $N=500$ respondents, Germany $N=528$ respondents, Italy $N=537$ respondents. Sampling was performed with the usage of the following online panels: Poland - epanel.pl and other countries - panels available on the Cint platform. The structure of the samples ensured representativeness by age, gender, size of the place of residence and region according to the structure of the population in each country for people aged 18-65. Research was done by an external company ARC Rynek i Opinia with the substantive and financial support of The Chamber of Fund and Asset Management (Izba Zarządzających Funduszami i Aktywami).
} 
European Parliament and of the Council of 24 March 2021. As is pointed out in the document, the impacts of the pandemic on patients, healthcare workers and healthcare systems are widespread [Komisja Europejska 2021].

EUR 5.3 billion in current prices will be invested by the European Union with EU4Health in the following actions:

1. Improving and fostering health in the European Union (disease prevention and health promotion, international health initiatives and cooperation).

2. Tackling, preventing, preparing and responding to cross-border health threats, complementing national stockpiling of essential crisis-relevant products and establishing a reserve of medical, healthcare and support staff.

3. Improving medicinal products, medical devices and crisis-relevant products, making them available and affordable for everyone.

4. Strengthening health systems, their resilience and resource efficiency, health data, digital tools and services, digital transformation of healthcare, improving access to healthcare, developing and implementing European Union health legislation and evidence-based decision making and integrating work among national health systems.

Caring for health, which is influenced by diet, is correlated with the income situation of a household. Income is the basic economic determinant of purchasing behaviour, including expenditure on food [Rudnicki 2012]. During the pandemic, according to the aforementioned study by Dąbrowska and Janoś-Kresło, in Poland $57.4 \%$ of respondents stated that their income during the pandemic did not change, which may indicate the possibility of satisfying needs at the current level. Every third Pole felt a worsening in their income situation, and $4.3 \%$ declared that their income had increased. Therefore, it can be said that for the nutrition of working people and those using a box diet, the income situation should not pose a threat to meeting the needs.

\section{MATERIAL AND METHODS}

The main goal of the article is to evaluate the health status of Poles in the context of their dietary patterns. Results of a desk research study on dietary habits of persons working during the pandemic and attitudes of Poles towards meal delivery services provided to the authors of the article by external research institutions were utilized for the purpose of this paper. The topic of consumer behaviour and decision-making has gained scientific and research interest during the pandemic. Since health is one of the most important values in human life, as already noted in this paper, a research on healthy eating should be treated as a significant, relevant and interesting research area.

A study on dietary patterns of peoples working during the pandemic was conducted by ABR SESTA [2020] in cooperation with Fitness Catering on a sample $N=800$ professionally active Poles living in urban areas, and in the countryside situated no more than 20 kilometres from the nearest city, using the ComputerAssisted Web Interview (CAWI) method. The sampling method enabled statistical inference with 0.95 confidence level and maximum error of estimation $3 \%$. The study was conducted on April 15-21, 2021 2 .

One of the goals of the study, as emphasized by Jurowczyk from ABR SESTA, was to identify what differentiates the respondents' declarations. It has been hypothesized that employee benefits related to nutrition have a positive effect on the feeling of physical and mental well-being.

An online survey (CAWI) on a representative sample of 1012 Polish residents, in which respondents were asked about the types of diets they consumed and their approach to meal delivery services was conducted by ABR SESTA in cooperation with the local branch of a global company, Syno International - SYNO Polska. Additional participants were Cateromarket.pl, Fitness Catering and the Association of Entrepreneurs of the Dietary Catering Industry. The survey took place on August 31-September 2, 2020 in order to identify the

\footnotetext{
${ }^{2}$ In the framework of practical scientific cooperation, the following reports containing results of research on dietary patterns of people working during the pandemic have been made available by external institutions for the purpose of this study: "Healthy, speedy or conveniently?" and "Healthy eating". The results were used with retain of copyright and ethical principles.
} 
attitudes of Poles to meal delivery services. The study took into account the following socio-economic characteristics: gender, age, voivodship, town size, education, financial situation, size of household, the number of offspring and professional status.

Respondents who participated in the study agreed to share their opinion on meal delivery services. The project was implemented in accordance with ISO quality standards and ESOMAR guidelines. The target group was women and men aged 18-65. The structure of the sample followed the national structure in terms of age, gender and size of locality in order to ensure a balanced representation of the views of the entire population.

The Bonferroni two-tailed post hoc equality test was used in statistical analysis for the purpose of this study. This statistic compares all pairs of the independent variable with the Student's $t$-test $(p<0.05)$, with a simultaneous control of the number of comparisons.

\section{HEALTH STATUS AND LIFESTYLE OF POLES BEFORE, AFTER AND DURING THE PANDEMIC}

According to the report on health status of Poles prepared by Statistics Poland in 2019, 66.3\% of adults assess their overall health well or very well. The report was based on The European Health Interview Survey (EHIS) results in 2019. The outcomes do not differ significantly from an analogous evaluation from 2014. High blood pressure and lower back pain are the most common chronic diseases and ailments affecting more than a quarter of respondents - sequentially: $26.5 \%$ and $25.8 \%$, followed by thyroid diseases $-9.5 \%$, diabetes $-8.1 \%$ and coronary artery disease $-7.5 \%$ of those interviewed.

As indicated in the report "National Quiz on Health Status of Poles in 2021", the Average Health Index in 2021 amounted to barely $54.7 \%-7.2$ p.p. less than the previous year, meaning that Poles took less care of their health [Medonet 2021]. Significant differences between age groups were observed, reflecting an increasing tendency with ageing. Within the age group $18-24$ years the index was at $51.3 \%$, whereas the most remarkable increase was witnessed between the age groups $45-54$ and 55-64 years old
$-1.9 \%$ difference in the favour of the second group. However, the index contracted most notably (minus 9.3 p.p.) in the age group $65+-$ a decrease from 67.7 to $58.4 \%$, year on year. Women generally score higher on the Average Health Index in comparison to men, indicating that women may possess a higher level of health literacy associated with taking care of their health, and that they may introduce rules for a healthier lifestyle into their lives to a greater extent. The results of the study show that improvements in lifestyles of Poles are required, including a need for healthier food intake, stimulant reduction, and increased physical activity.

Lifestyle is an interdisciplinary term. The topic has even attracted the interest of such authors as Marx, Simmel, Adler, Wirth, Weber, Giddens, Boudieu, Dahrendorf and Crawford. Polish authors have also taken an interest: Znaniecki, Ossowski, Chałasiński, Jawłowska, Siciński, Ostrowska, Szalonka. Authors such as Lubowiecki-Vikuk, Dąbrowska and Machnik have also reviewed the lifestyles of responsible consumers in the context of the sustainable development paradigm [Lubowiecki et al. 2021].

In sociology, lifestyle is viewed as an interpretation of social position and as a basis for the social identification of individuals and communities [Ostrowska 1999]. The meaning of lifestyle in the point of view of psychology is a set of overt, manifested behaviours and typical reactions of certain elements of the personality [Wrześniewski 1993], or as the ability to anticipate difficulties and mobilize to overcome and to actively deal with them [Rodin and Salovey 1997].

In medical sciences, pro health lifestyles are being associated with a certain way of eating, physical exercise, avoiding smoking tobacco and also - as pointed out in more current papers - the ability to cope with stress in everyday life [Ostrowska 1999]. According to Abel [1991] healthy lifestyles are not solely patterns of behaviour related to health, but also values and attitudes represented by people as a response to the conditions of their social, cultural and economic environment. In the economic context, lifestyle is understood as "the distinctive pattern of personal and social behaviour characteristic of an individual or a group" [Veal 1993]. 
A noteworthy conception of the term was proposed by the Polish author Siciński, who explains lifestyle as scope and forms of everyday behaviour, specific for a certain social community or an individual, i.e. a characteristic "way of being" in society. Simultaneously the author indicates the following functions of a lifestyle:

- it serves as a signalling tool - evidence of belonging to a given social group, and thus creates a sense of social bond, provides individuals with the possibility of social self-identification by giving them a sense of security, etc. (collective aspect);

- it distinguishes a given group from a wider community (consisting of other groups), contributes to the durability of this group, its continuity despite the "exchangeability" of individual units that make it up over time (collective aspect);

- it outlines the possibilities of expressing the personality of an individual in a socially acceptable way (individual aspect) [Siciński 1988].

Lifestyle is also associated with consumer behaviour, including pro-health. Pro-health behaviours and lifestyles are interconnected. In the period before the pandemic, and in the pandemic especially, Poles began to pay more attention to health issues, including maintaining or restoring or achieving a proper, healthy body shape, fighting diabetes, etc. As the essence of the meal delivery services is to fulfill all of a person's nutritional needs and adjust diets (calorie and nutrition intake) to the situation of each client, it could be seen as an effective tool in achieving goals that have been set. However, special care should be taken when choosing such services, taking into account such particulars as: name and surname of a nutritionist, actual personalization of meals, detailed information on the contents of the products. Meals should be cooked with fresh ingredients, delivered directly to the customer's door.

As pointed out in the monograph "Selected problems of nutrition prophylaxis and diet therapy in chronic diseases", based on the results of a study, it was found that individual dietary catering may be beneficial especially for people who do not have adequate knowledge in the field of healthy eating or do not have time to prepare meals, but want to lose weight or stabilize the blood glucose level [Gajewska and Mysz-
kowska-Ryciak 2016]. Typically, such diet consists of five meals per day that should be consumed in regular intervals (usually every three hours). The calorie intake is predefined by the customer whereas personalised nutrition is based on such characteristics as: gender, lifestyle, including physical activity and the nature of the work performed as well as presence of diseases, if any.

The following diets are offered on the meal delivery services market:

- vegetarian diet,

- vegan diet,

- gluten-free diet,

- lactose-free diet,

- paleo diet, and more.

It could be stated that pre-boxed diets should be pro-health adapted and tailor-made to customer needs. However, whereas such services may not be the cheapest solution, they are often used by overworked people with heavy responsibilities, who do not enjoy shopping and cooking, as well by those who find it difficult to prepare well-balanced and healthy meals on a regular basis.

\section{EATING HABITS OF WORKING POLES DURING THE PANDEMIC}

According to the study by ABR SESTA and Fitness Catering, $68 \%$ of respondents agreed to the statement that healthy eating is important for Polish people. No significant difference in distribution of responses between males and females, nor between age groups, was observed. One in two professionally active Poles declared to have paid more attention to healthy dieting during the pandemic. Such an attitude was more common within female respondents $(54 \%)$ as well as in the age group of 25-34 years old (57\%). A proper balance of nutrients and ensuring a variety of foods seems to be the most challenging. More than one third $(37 \%)$ of working Poles is on a specific diet, the most common is the light diet. $62 \%$ of those interviewed pay attention to proper hydration, $51 \%$ attach importance to good nutrition and try to buy healthy foods $(50 \%)$.

Gender is the variable that differentiates the behaviour of respondents in the context of taking care of daily diet - see Table 1 . 
Table 1. Healthy eating habits among Poles

\begin{tabular}{|c|c|c|c|c|}
\hline Ways to maintain a healthy eating lifestyle & $\begin{array}{l}\text { In total } \\
(\%)\end{array}$ & $\begin{array}{c}\text { Males } \\
(\%)\end{array}$ & $\begin{array}{c}\text { Females } \\
(\%)\end{array}$ & $\begin{array}{l}\text { Age group with the highest frequency } \\
\text { of indications }\end{array}$ \\
\hline I cook / prepare healthy meals for myself & 81 & 77 & 83 & $\begin{array}{c}\text { ages } 25-34 \text { years } \\
87 \%\end{array}$ \\
\hline I eat a few daily servings of fruits and vegetables & 65 & 60 & 69 & $\begin{array}{c}\text { ages } 25-34 \text { years } \\
70 \%\end{array}$ \\
\hline I limit sugary and fizzy drinks & 60 & 55 & 63 & $\begin{array}{c}\text { ages } 25-34 \text { years } \\
61 \%\end{array}$ \\
\hline I limit unhealthy snacks during the day & 55 & 51 & 59 & $\begin{array}{c}\text { ages } 25-34 \text { years } \\
58 \%\end{array}$ \\
\hline $\begin{array}{l}\text { I drink the recommended amount of water } \\
\text { throughout the day }\end{array}$ & 53 & 50 & 55 & $\begin{array}{l}\text { ages } 18-24 \text { and } 25-34 \text { years } \\
54 \% \text { each }\end{array}$ \\
\hline I limit sodium intake & 47 & 45 & 49 & $\begin{array}{l}\text { ages } 55+\text { years } \\
55 \%\end{array}$ \\
\hline I buy eco-friendly/bio- products & 38 & 32 & 41 & $\begin{array}{c}\text { ages } 25-34 \text { years } \\
42 \%\end{array}$ \\
\hline I buy healthy takeaways & 18 & 18 & 18 & $\begin{array}{c}\text { ages } 55+\text { years } \\
21 \%\end{array}$ \\
\hline I use healthy meal delivery services & 8 & 8 & 8 & $\begin{array}{c}\text { ages } 25-34 \text { years } \\
10 \%\end{array}$ \\
\hline $\begin{array}{l}\text { I follow a diet set by a professional dietitian by } \\
\text { preparing meals for myself }\end{array}$ & 6 & 6 & 5 & $\begin{array}{c}\text { ages } 25-34 \text { years } \\
8 \%\end{array}$ \\
\hline
\end{tabular}

Source: [Fitness Catering 2021].

\section{ATTITUDES OF POLES TOWARDS MEAL DELIVERY SERVICES IN LIGHT OF THE STUDY}

At the beginning of the study respondents were asked about their opinion on meal delivery services. One in ten is not familiar with such services whereas $39 \%$ have heard about it in the past (Fig. 1.) A noteworthy fact is that about $7 \%$ have used meal delivery services in the past but gave up on it, while $11 \%$ do not use them but consider doing so in the future. At this time about $2 \%$ of Poles use meal delivery services.

One in three was interested in meal delivery services but have never used them so far. Such observation was more common for women (36\%, statistically significant) than for men (26\%), young persons between the ages 18 and 24 years (36\%, statistically significant) than persons in the age group $34-44$ years $(34 \%$, statistically significant), those who have a college or university degree (36\%) rather than basic vocational education (13\%), living in towns with 100,000-199,000 and $200,000-499,000$ population $(36 \%$ each, statisti- cally significant), assessing the situation of their households as average - "we have enough every day" (34\%, statistically significant) rather than as modest - "we live modestly - we spare money on an everyday basis" (21\%), from a minimum 3-person household (33\%), students $(41 \%$, statistically significant) more than unemployed $(10 \%)$ and retirees and pensioners $(16 \%)$.

The aim of the research was to identify the determinants of willingness to use meal delivery services within the respondents. It turned out that the main reason, for more than $50 \%$ of respondents, was lack of time for self-preparation of food followed by the need or desire to lose weight (46\%). One third of Poles indicated savings or elimination of certain ingredients from diet as reasons for subscribing to meal delivery services (Fig. 2.).

Lack of time for self-preparation of food was indicated more often by women ( $55 \%$ statistically significant), young persons between the ages of 18 and 24 years $(68 \%)$ more than persons between the ages 45 and 65 years, those who have a college or university degree 
I have heard of meal delivery services but I do not know much more about it

I am interested in meal delivery services but I have never tried it so far

I do not use meal delivery services at the moment but I consider to do so in the future

I have never heard of meal delivery services

I do not use meal delivery services at the moment but I had done it in the past

I use meal delivery services

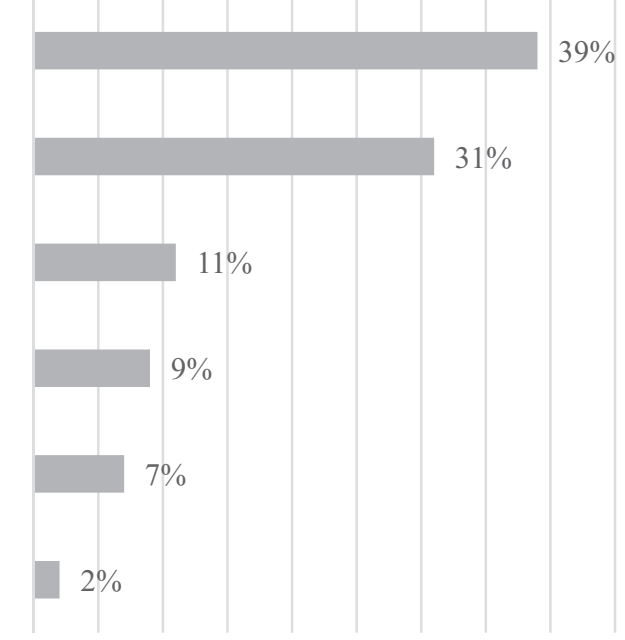

$0 \% \quad 5 \% \quad 10 \% \quad 15 \% \quad 20 \% 25 \% 30 \% 35 \% 40 \% 45 \%$

Fig. 1. Attitudes of Poles towards meal delivery services Source: [Fitness Catering 2021].

No time for self-preparation of foods

Need to lose weight

Money savings in comparision to eating out

Elimination of certain ingridients from diet

Lack confidence and skills in the kitchen / /no ideas for meals

Need to gain weight

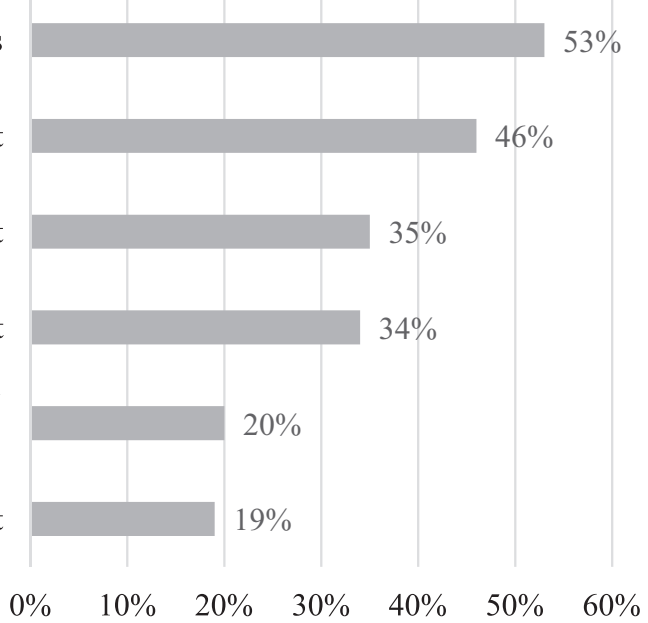

Fig. 2. Reasons for using diet caterings

Source: [Fitness Catering 2021].

(54\%), living in towns with 100,000-199,000 population, assessing the situation of their households as average - "we have enough every day" (61\%, statistically significant) more than very well - "we can afford the luxury" (21\%), from 3-person households (57\%, statistically significant), students (69\%, statistically significant) more than persons doing the housework ( $28 \%$, statistically significant) or retirees and pensioners $(22 \%)$.
A need to lose weight was declared more often by women (50\%, statistically significant) than men (39\%, statistically significant), persons between the ages 35 and 44 years $(53 \%)$, persons with lower secondary or secondary education ( $50 \%$, statistically significant), living in towns with 10,000 and 49,000 population (50\%, statistically significant), assessing the situation of their households very well - "we can afford the 


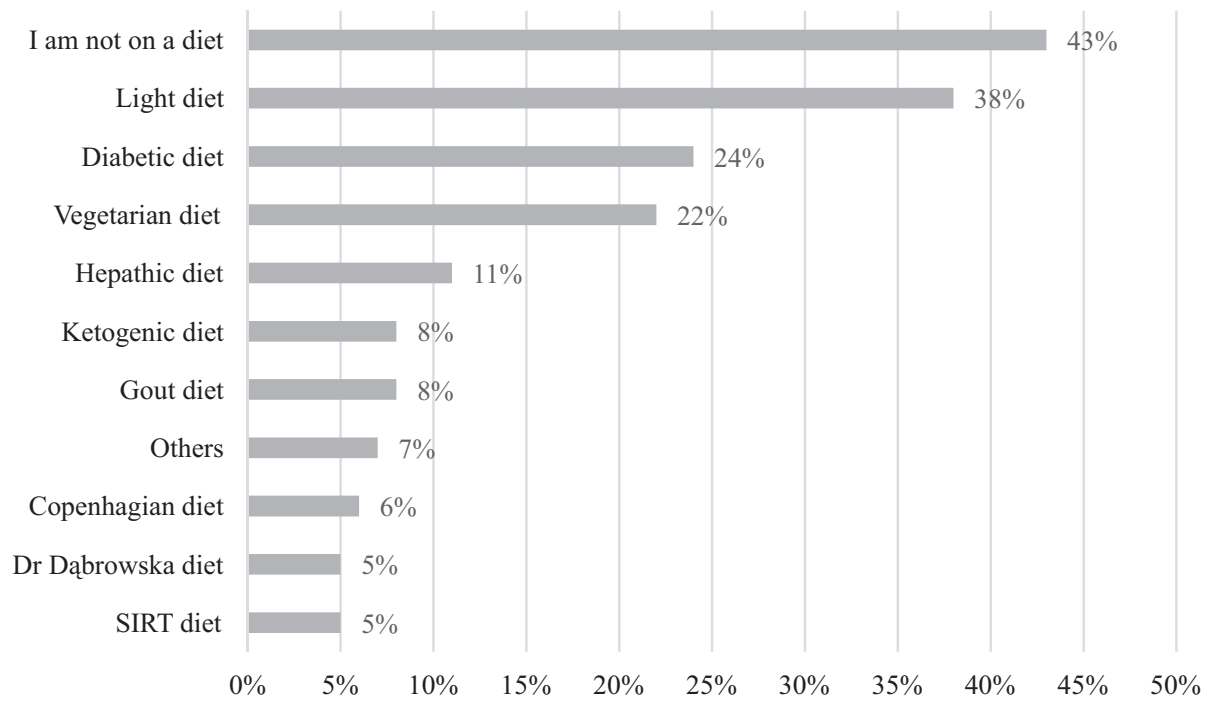

Fig. 3. Diets followed by Poles

Source: [Fitness Catering 2021].

luxury (58\%, statistically significant), from 3-person households (51\%, statistically significant), professionally active or unemployed/looking for a job (47\% each).

Following a certain diet is a common reason of using meal delivery services as it helps to obey dietary rules. $43 \%$ of interviewed respondents do not diet. A light diet is the most frequent among those who stick to a diet (38\%) followed by a diabetic diet (24\%) and a vegetarian diet (22\%) (Fig. 3.).

The results of the study show that $9 \%$ of Poles were not familiar with meal delivery services; this statement is particularly true for men at the age of 55 or above. The remaining respondents have heard about such services before, showed an interest in using them or consider doing so in the future. Women and young people (18-24 years old) are more interested in the meal delivery services, but people aged 25-34 are the most willing to take advantage of such offers.

\section{CONCLUSIONS}

The rising awareness among consumers, especially young consumers, could be observed in light of the results of the study presented in this paper. Nowadays, consumers play a key role in the market; being rela- tively autonomous in their own decisions and market choices, they present a considerable challenge for many companies. An increasing interest in healthy diets implies that there are several transformations on the market as well as a necessity to adapt to the shifting needs and expectations of customers.

The pandemic brought significant changes into consumers' lives and existing routines. Working from home as well as remote learning seem to be the key trend in consumer behaviour. However, it is worth emphasizing that consumers are also using self-services to a greater degree - self-preparation of meals, baking cakes, bread or preserving, etc. Such behaviour was declared by 41.9\% Poles, $33.9 \%$ Germans and $53.1 \%$ Italians.

A greater importance was attached to such issues as healthy diets, proper nutrition and self-preparation of meals by consumers during the pandemic. The respondents who participated in the study paid more attention to time management in order to be able to prepare healthy and nutritious meals, as well as to the quality of the products they purchased.

Encouraged by the rising interest in healthy diets among Poles, the authors see a need to extend the research on consumers who use meal delivery services, and to go deeper into the analysis of socio-demographic variables in shaping consumer behavior. 


\section{REFERENCES}

Abel, T. (1991). Measuring health lifestyles in a comparative analysis: Theoretical issues and empirical findings. Social Science and Medicine 32(8), 899-908.

ABR Sesta (2020). Raport „Zdrowe odżywianie”. Retrieved from https://abrsesta.com/produkt/zdrowe-odzywianie/ [accessed 10.11.2020].

Gajewska, D., Myszkowska-Ryciak, J. (2016). Wybrane problemy dietoprofilaktyki i dietoterapii chorób przewlekłych. Polskie Towarzystwo Diabetyki, Warszawa. Retrieved from https://ptd.org.pl/sites/default/files/ monografia_ptd_2016.pdf [accessed 13.07.2021].

Harari, J.N. (2015). Od zwierząt do bogów. Dom Wydawniczy PWN, Warszawa.

Kochanowski, J. (n.d.). On health [transl.] J. Zawadzki. Retrieved from https://wolnelektury.pl/media/book/pdf/kochanowski-on-health.pdf [accessed 13.07.2021]

Komisja Europejska (2021). Program UE dla zdrowia 2021-2027 - wizja zdrowszej Unii Europejskiej. Retrived from https://ec.europa.eu/health/funding/eu4health pl [accessed 13.07.2021].

Lubowiecki-Vikuk, A., Dąbrowska, A., Machnik, A. (2021). Responsible consumer and lifestyle: Sustainability insight, Sustainable Production and Consumption 25, $91-$ -101, https://doi.org/10.1016/j.spc.2020.08.007.

Medonet (2021). Narodowy Test Zdrowia Polaków. Raport 2021. Retrived from https://narodowytestzdrowia.medonet.p1/ [accessed 13.07.2021].
Ostrowska, A. (1999). Styl życia a zdrowie. Wydawnictwo IfiS PAN, Warszawa.

Fitness Catering (2021). Raport. Zdrowo, szybko czy wygodnie? Raport o odżywianiu pracowników w czasie pandemii. Retrieved from https://fitnesscatering.com. pl/RAPORT-ccms-pol-186.html [accessed 20.06.2021].

Rodin, J., Salovey, P. (1997). Psychologia zdrowia. [In:] J. Heszen-Niejodek, M. Sęk (Eds), Psychologia zdrowia. PWN, Warszawa.

Rudnicki, L. (2012). Zachowania konsumentów na rynku. PWE, Warszawa.

Siciński, A. (Ed.) (1988). Style życia w miastach polskich (u progu kryzysu). Ossolineum, Wrocław.

Statistics Poland (2019). Health and health care in 2019, Warszawa. Retrieved from https://stat.gov.pl/en/topics/ health/ [accessed 13.07.2021].

Statistics Poland (2020). Population. Size and structure and vital statistics in Poland by territorial division. As of December 31, 2020, Warszawa.

Veal, A.J. (1993). The concept of lifestyle: A review. Leisure Studies 12(4), 233-252.

WHO (2006). Constitution of the World Health Organization. Retrived from https://www.who.int/governance/eb/ who_constitution_en.pdf [accessed 13.07.2021].

WHO (2021). World Health Day 2021. Retrieved from https://www.who.int/campaigns/world-health-day/2021 [accessed 28.06.2021].

Wrześniewski, K. (1993). Styl życia a zdrowie. Wzór zachowania. PZWL, Warszawa.

\section{ZDROWIE POLAKÓW A SPOSÓB ODŻYWIANIA SIĘ}

\section{STRESZCZENIE}

Celem artykułu jest ocena zdrowia Polaków w kontekście odżywiania się. Wykorzystano badania desk research udostępnione autorkom przez firmy, które badały dwie kwestie, a mianowicie - odżywianie osób pracujących w czasie pandemii oraz stosunek Polaków do diety pudełkowej. W ramach współpracy praktyka-nauka firmy udostępniły autorkom raporty z wynikami badań „Zdrowo, szybko czy wygodnie? - o odżywianiu pracowników w czasie pandemii oraz „Zdrowe odżywianie”. Wyniki wykorzystano z zachowaniem praw autorskich i zasad etycznych. Na podstawie analizy wyników badania postawiono tezę, że w okresie pandemii częściej zwracamy uwagę na to, co jemy, poświęcamy także więcej czasu na samodzielne przygotowanie posiłków. Przyjmując za GUS, że populacja Polski w 2020 roku wynosiła 38265 tysięcy osób, to w świetle wyników badania można powiedzieć, że prawie 650 tysięcy Polaków miało dobrze zbilansowaną dietę dostosowaną do potrzeb konsumenta.

Słowa kluczowe: dieta, zdrowie, odżywianie się, Polska 